Supporting Information

for

\title{
A Two-Dimensional Spin-Crossover Coordination Polymer Exhibiting Interlayer Multiple $\mathbf{C}-\mathbf{H}^{\delta+\ldots} \mathbf{H}^{\delta^{-}}-\mathbf{B}$ Dihydrogen Bonds
}

Jin-Peng Xue, Wen-Jie Wu, Quan-Song Li, Zi-Shuo Yao,* and Jun Tao*

Key Laboratory of Cluster Science of Ministry of Education, School of Chemistry and Chemical Engineering, Liangxiang Campus, Beijing Institute of Technology, Beijing 102488, People's Republic of China.

*E-mail: taojun@bit.edu.cn; zishuoyao@bit.edu.cn 


\section{Table of Contents}

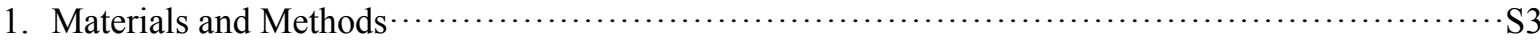

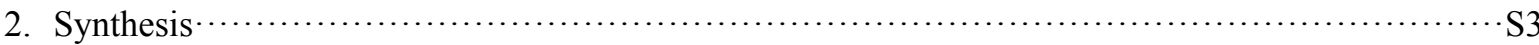

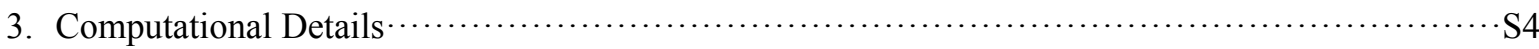

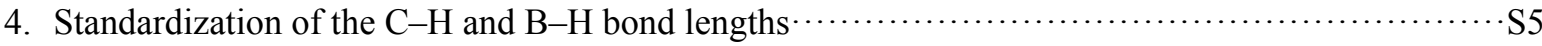

5. Additional Tables

Table S1. Crystal data and structural refinements for $1 \cdot 5 \mathrm{C}_{2} \mathrm{Cl}_{4} \cdot 4 \mathrm{CH}_{3} \mathrm{OH} \cdots \cdots \cdots \cdots \cdots \cdots \cdots \cdots \cdots \cdots \cdots \cdots \cdots \cdots \cdots \cdots$

Table S2. The experimental values for selected distances and angles of $\mathrm{C}-\mathrm{H}^{\delta+} \cdots \mathrm{H}^{\delta-}-\mathrm{B}$ DHBs interactions of $1 \cdot 5 \mathrm{C}_{2} \mathrm{Cl}_{4} \cdot 4 \mathrm{CH}_{3} \mathrm{OH}$ at $123 \mathrm{~K} \cdots \cdots \cdots \cdots \cdots \cdots \cdots \cdots \cdots \cdots \cdots \cdots \cdots \cdots \cdots \cdots \cdots \cdots \cdots \cdots \cdots \cdots$

Table S3. Selected bond lengths and angles for $1 \cdot 5 \mathrm{C}_{2} \mathrm{Cl}_{4} \cdot 4 \mathrm{CH}_{3} \mathrm{OH}$ at $293 \mathrm{~K} \cdots \cdots \cdots \cdots \cdots \cdots \cdots \cdots \cdots \cdots \cdots \cdots \cdots$

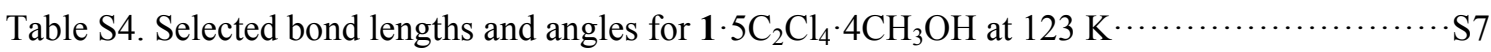

6. Additional Figures

Figure S1. Temperature-dependent $\chi_{\mathrm{M}} T$ values and variable-temperature crystal colours of

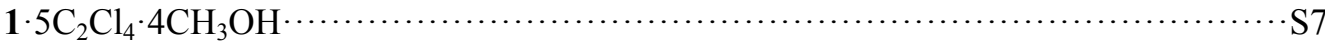

Figure S2. Coordination environment of the $\mathrm{Fe}^{\mathrm{II}}$ atom in $1 \cdot 5 \mathrm{C}_{2} \mathrm{Cl}_{4} \cdot 4 \mathrm{CH}_{3} \mathrm{OH}$ at $298 \mathrm{~K}$ and $123 \mathrm{~K} \cdots \mathrm{S} 8$

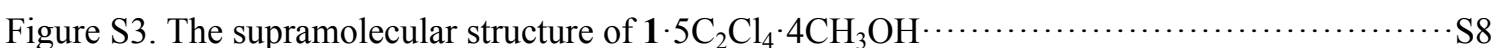

Figure S4. Another imaginary ABAB-stacked structure, in which the $\mathrm{NCBH}_{3}^{-}$groups point to the windows of adjacent layers

Figure S5. Temperature-dependent $\chi_{\mathrm{M}} T$ values and the variable-temperature $b$-axis values of $1 \cdot 5 \mathrm{C}_{2} \mathrm{Cl}_{4} \cdot 4 \mathrm{CH}_{3} \mathrm{OH} \cdot$

Figure S6. Temperature-dependent $\chi_{\mathrm{M}} T$ values of $1 \cdot 5 \mathrm{C}_{2} \mathrm{Cl}_{4} \cdot 4 \mathrm{CH}_{3} \mathrm{OH}$ (black), $1 \cdot 3 \mathrm{CHCl}_{3} \cdot 4 \mathrm{CH}_{3} \mathrm{OH}$ (blue), and $\mathbf{1} \cdot 2 \mathrm{C}_{6} \mathrm{H}_{6} \cdot 4 \mathrm{CH}_{3} \mathrm{OH}$ (red)

Figure S7. Thermogravimetric analysis of $\mathbf{1} \cdot 5 \mathrm{C}_{2} \mathrm{Cl}_{4} \cdot 4 \mathrm{CH}_{3} \mathrm{OH}, \mathbf{1} \cdot 3 \mathrm{CHCl}_{3} \cdot 4 \mathrm{CH}_{3} \mathrm{OH}, \mathbf{1} \cdot 2 \mathrm{C}_{6} \mathrm{H}_{6} \cdot 4 \mathrm{CH}_{3} \mathrm{OH}$, and 1

Figure S8. Variable-temperature powder X-ray diffraction pattern of compound $1 \cdot 5 \mathrm{C}_{2} \mathrm{Cl}_{4} \cdot 4 \mathrm{CH}_{3} \mathrm{OH}$ in

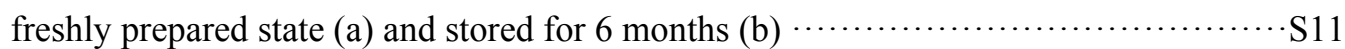

Figure S9. Powder X-ray diffraction pattern of compounds of $1 \cdot 5 \mathrm{C}_{2} \mathrm{Cl}_{4} \cdot 4 \mathrm{CH}_{3} \mathrm{OH}, \mathbf{1} \cdot 3 \mathrm{CHCl}_{3} \cdot 4 \mathrm{CH}_{3} \mathrm{OH}$, $\mathbf{1} \cdot 2 \mathrm{C}_{6} \mathrm{H}_{6} \cdot 4 \mathrm{CH}_{3} \mathrm{OH}$ and 1 encapsulating $\mathrm{CH}_{3} \mathrm{OH}$ and $\mathrm{C}_{2} \mathrm{Cl}_{4}$ at $298 \mathrm{~K} \cdots \cdots \cdots \cdots \cdots \cdots \cdots \cdot \mathrm{S} 12$

Figure S10. Electrostatic potential diagram and extreme value of $\mathrm{C}_{6} \mathrm{H}_{6} \cdots\left[\mathrm{NCBH}_{3}^{-}\right]$complex $\cdots \cdots \cdots \mathrm{S} 12$

Figure S11. The dihydrogen bonds portion in the structure and electron density and molecular configuration of $\mathrm{C}_{6} \mathrm{H}_{6} \cdots\left[\mathrm{NCBH}_{3}^{-}\right]$complex $\cdots \cdots \cdots \cdots \cdots \cdots \cdots \cdots \cdots \cdots \cdots \cdots \cdots \cdots \cdots \cdots \cdots \cdots \cdots \cdots \cdots \cdots \cdots \cdots$

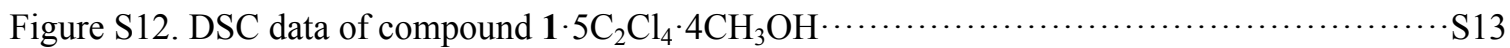

Figure S13. IR spectra of compounds $\mathbf{1} \cdot 5 \mathrm{C}_{2} \mathrm{Cl}_{4} \cdot 4 \mathrm{CH}_{3} \mathrm{OH}, \mathbf{1} \cdot 3 \mathrm{CHCl}_{3} \cdot 4 \mathrm{CH}_{3} \mathrm{OH}, \mathbf{1} \cdot 2 \mathrm{C}_{6} \mathrm{H}_{6} \cdot 4 \mathrm{CH}_{3} \mathrm{OH}, \mathbf{1}$

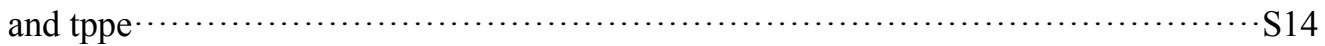

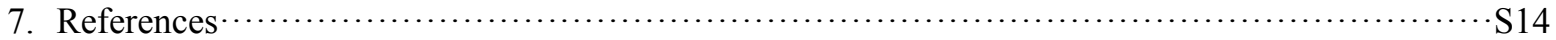




\section{Materials and Methods}

Iron(II) chloride tetrahydrate and sodium cyanoborohydride were purchased from Alfa Aesar and Aladdin, respectively. 1,1,2,2-tetrakis(4-(pyridin-4-yl)phenyl)ethane (tppe) was obtained from TCI Shanghai (China). Perchloroethylene was purchased from Aladdin and the other solvents were purchased from Beijing Tong Guang Fine Chemicals Company (China). All reagents were used without further purification.

Variable- and room-temperature powder X-ray diffraction data were recorded on a PANalytical diffractometer with $\mathrm{Cu} K \alpha$ radiation equipped with a TTK450 accessory in the temperature range from $123 \mathrm{~K}$ to $473 \mathrm{~K}$ at an interval of $25 \mathrm{~K}$.

Magnetic measurements were performed on Quantum Design MPMS XL7 magnetometer working in the $2-400 \mathrm{~K}$ temperature range with $1 \mathrm{~K} \mathrm{~min}^{-1}$ sweeping rate under a magnetic field of $5000 \mathrm{Oe}$.

Infrared spectra ( $\mathrm{KBr}$ pellets) were conducted in the range of $400-4000 \mathrm{~cm}^{-1}$ on a Thermo IS5 spectrometer. Elemental analyses for $\mathrm{C}, \mathrm{H}$, and $\mathrm{N}$ were performed on a EUROVECTER EA3000 analyzer.

Differential scanning calorimetry (DSC) measurements were recorded in an aluminium closed pan on PerkinElmer DSC 8000.

Thermogravimetric (TG) analyses were carried out under nitrogen atmosphere on a TG-DTA 6200 instrument with a heating rate of $10{ }^{\circ} \mathrm{C} \mathrm{min}^{-1}$.

Single-crystal X-ray diffraction data were recorded on a Rigaku Oxford XtaLAB PRO diffractometer with graphite-monochromated Mo $K \alpha$ radiation $(\lambda=0.71073 \AA$ ) at 293 and $123 \mathrm{~K}$, respectively. The structure was solved by direct methods and further refined by full-matrix least-squares techniques on $F^{2}$ with SHELXL-97. ${ }^{1}$ Non-hydrogen atoms were refined anisotropically, and the hydrogen atoms were generated geometrically and refined isotropically. Attempts to define the highly disordered solvent molecules were unsuccessful, so the structure was refined with the PLATON² "SQUEEZE" procedure. Void channels were calculated by Mercury "Void" command. CCDC numbers: $\mathbf{1} \cdot \mathbf{5} \mathrm{C}_{\mathbf{2}} \mathbf{C l}_{\mathbf{4}} \cdot \mathbf{4} \mathbf{C H}_{\mathbf{3}} \mathrm{OH}$ at

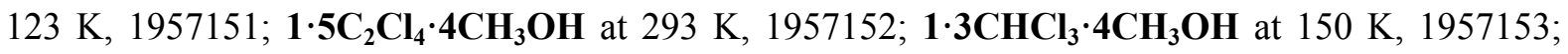
$\mathbf{1} \cdot 2 \mathbf{C}_{6} \mathbf{H}_{6} \cdot \mathbf{4} \mathbf{C H}_{3} \mathbf{O H}$ at $295 \mathrm{~K}, 1957154$.

\section{Synthesis}

Synthesis of $\mathbf{1} \cdot \mathbf{5 C}_{2} \mathbf{C l}_{\mathbf{4}} \cdot \mathbf{4} \mathbf{C H}_{3} \mathrm{OH}$ : A $4 \mathrm{~mL}$ tetrachloroethylene $(\mathrm{TCE}) / \mathrm{CH}_{3} \mathrm{OH}$ solution $(\mathrm{v} / \mathrm{v}=3: 1)$ of tppe $(12.8 \mathrm{mg}, 0.02 \mathrm{mmol})$ was placed in one side of an $\mathrm{H}$-type tube, and a $\mathrm{CH}_{3} \mathrm{OH}$ solution $(5 \mathrm{~mL})$ of $\left[\mathrm{Fe}\left(\mathrm{NCBH}_{3}\right)_{2}\right](0.05 \mathrm{mmol}$ in $5 \mathrm{ml})$ was placed in another side of the H-type tube. Then, methanol was 
carefully added to the top of the two solutions until the H-type tube was entirely filled. After 3 weeks, bright yellow crystals suitable for X-ray diffraction analysis were obtained. The amount of solvent molecules in the crystal was estimated by elemental and thermogravimetric analyses. FTIR (KBr pellet, $\mathrm{cm}^{-1}$ ): 738, 758, 817, 1006, 1115, 1223, 1400, 1491, 1539, 1607, 2181, 2340, 3031. Elemental analysis calcd (\%) for $\mathrm{C}_{62} \mathrm{H}_{54} \mathrm{O}_{4} \mathrm{~N}_{6} \mathrm{~B}_{2} \mathrm{Cl}_{20} \mathrm{Fe}$ : C 42.96, $\mathrm{H} 3.14, \mathrm{~N}$ 4.85; found: $\mathrm{C} 43.01, \mathrm{H}$ 3.04, $\mathrm{N}$ 4.84. Elemental analysis calcd (\%) for the solvent-free sample (under vacuum at $80{ }^{\circ} \mathrm{C}$ for $8 \mathrm{~h}, \mathrm{C}_{48} \mathrm{H}_{38} \mathrm{~N}_{6} \mathrm{~B}_{2} \mathrm{Fe}$ ): $\mathrm{C} 74.26$, H 4.93, N 10.83. Found C 74.14, H 4.87, N 10.81. IR (KBr pellet, $\left.\mathrm{cm}^{-1}\right)$ : 668, 738, 758, 817, 1006, $1068,1114,1223,1401,1490,1534,1608,2179,2358,3030$.

Synthesis of $\mathbf{1} \cdot \mathbf{3} \mathbf{C H C l}_{3} \cdot \mathbf{4 C H}_{3} \mathbf{O H}$ : A $4 \mathrm{~mL} \mathrm{CHCl}_{3} / \mathrm{CH}_{3} \mathrm{OH}$ solution $(\mathrm{v} / \mathrm{v}=1: 1)$ of tppe $(12.8 \mathrm{mg}$, $0.02 \mathrm{mmol})$ was placed in one side of an $\mathrm{H}$-type tube, and a $\mathrm{CH}_{3} \mathrm{OH}$ solution $(5 \mathrm{~mL})$ of $\left[\mathrm{Fe}\left(\mathrm{NCBH}_{3}\right)_{2}\right]$ (0.05 mmol in $5 \mathrm{ml})$ was placed in another side of the H-type tube. Then, methanol was carefully added to the top of the two solutions until the H-type tube was entirely filled. After 3 weeks, bright yellow crystals suitable for X-ray diffraction analysis were obtained. The amount of solvent molecules in the crystal was estimated by elemental and thermogravimetric analyses. FTIR ( $\mathrm{KBr}$ pellets, $\left.\mathrm{cm}^{-1}\right)$ : 507, $738,758,816,1006,1068,1113,1222,1399,1489,1539,1607,2179,2331,3029$. Elemental analysis calcd (\%) for $\mathrm{C}_{55} \mathrm{H}_{57} \mathrm{O}_{4} \mathrm{~N}_{6} \mathrm{~B}_{2} \mathrm{Cl}_{9} \mathrm{Fe}$ : C 52.40, $\mathrm{H} 4.40, \mathrm{~N}$ 6.67; found: C 52.34, $\mathrm{H}$ 4.55, N 6.60.

Synthesis of $\mathbf{1} \cdot \mathbf{2 C}_{6} \mathbf{H}_{\mathbf{6}} \cdot \mathbf{4} \mathbf{C H}_{3} \mathrm{OH}$ : A $4 \mathrm{~mL} \mathrm{C}_{6} \mathrm{H}_{6} / \mathrm{CH}_{3} \mathrm{OH}$ solution $(\mathrm{v} / \mathrm{v}=1: 3)$ of tppe $(12.8 \mathrm{mg}, 0.02$ mmol) was placed in one side of an $\mathrm{H}$-type tube, and a $\mathrm{CH}_{3} \mathrm{OH}$ solution $(5 \mathrm{~mL})$ of $\left[\mathrm{Fe}\left(\mathrm{NCBH}_{3}\right)_{2}\right](0.05$ mmol in $5 \mathrm{ml}$ ) was placed in another side of the H-type tube. Then, methanol was carefully added to the top of the two solutions until the H-type tube was entirely filled. After 3 weeks, bright yellow crystals suitable for X-ray diffraction analysis were obtained. The amount of solvent molecules in the crystal was estimated by elemental and thermogravimetric analyses. FTIR ( $\mathrm{KBr}$ pellets, $\mathrm{cm}^{-1}$ ): 738, $758,817,1006,1115,1223,1400,1490,1539,1607,2181,2340,3031$. Elemental analysis calcd (\%) for $\mathrm{C}_{64} \mathrm{H}_{66} \mathrm{O}_{4} \mathrm{~N}_{6} \mathrm{~B}_{2} \mathrm{Fe}$ : C 72.61, H 6.09, N 7.94; found: C 72.70, H 6.13, N 7.71.

Guest Exchange: Solvent exchanges were performed by immersion of the as-synthesized sample $1 \cdot 2 \mathrm{C}_{6} \mathrm{H}_{6} \cdot 4 \mathrm{CH}_{3} \mathrm{OH}(\sim 20 \mathrm{mg})$ in various ratios of $\mathrm{CH}_{3} \mathrm{OH}-\mathrm{C}_{2} \mathrm{Cl}_{4}$ mixed solvent $(20 \mathrm{~mL} ; 10: 0,9: 1,8: 2$, $7: 3,6: 4,5: 5,4: 6,3: 7,2: 8,1: 9,0: 10$ ) for 6 hours, and each exchange was successively conducted in freshly prepared $\mathrm{CH}_{3} \mathrm{OH}-\mathrm{C}_{2} \mathrm{Cl}_{4}$ mixed solvent for 5 times.

\section{Computational Details}

The geometries of the monomers and complex were fully optimized at the density functional theoryB3LYP method ${ }^{4}$ with $6-31+g(d, p)$ basis set. Vibrational frequency analysis was performed at the same theoretical level to ensure that the optimized geometries were local minima on their potential energy surfaces. The counterpoise technique proposed by Boys and Bernardi ${ }^{5}$ was used to rectify the 
interaction-energy calculation $(\Delta E)$, geometry optimizations, and frequency computations. All calculations were performed with the Gaussian 09 program package. ${ }^{6}$

\section{Standardization of the $\mathrm{C}-\mathrm{H}$ and $\mathrm{B}-\mathrm{H}$ bond lengths:}

The $\mathrm{C}_{6} \mathrm{H}_{6} \ldots \mathrm{NCBH}_{3}{ }^{-}$portion with normalised $\mathrm{C}-\mathrm{H}(1.09 \AA)$ and $\mathrm{B}-\mathrm{H}(1.21 \AA)$ bonds were modelled with AutoCAD software. The coordinates of the hydrogen atom were obtained by the model and hydrogen atoms were generated by Material studios.

\section{Additional Tables}

Table S1. Crystal data and structural refinements for $1 \cdot 5 \mathrm{C}_{2} \mathrm{Cl}_{4} \cdot 4 \mathrm{CH}_{3} \mathrm{OH}$

\begin{tabular}{|c|c|c|}
\hline \multicolumn{3}{|c|}{$\mathbf{1} \cdot 5 \mathrm{C}_{2} \mathrm{Cl}_{4} \cdot 4 \mathrm{CH}_{3} \mathrm{OH}$} \\
\hline$T / \mathrm{K}$ & 293 & 123 \\
\hline Formula & \multicolumn{2}{|c|}{$\mathrm{C}_{64} \mathrm{H}_{58} \mathrm{~B}_{2} \mathrm{~N}_{6} \mathrm{O}_{4} \mathrm{Cl}_{20} \mathrm{Fe}$} \\
\hline$M_{\mathrm{r}} / \mathrm{g} \mathrm{mol}^{-1}$ & \multicolumn{2}{|c|}{1723.75} \\
\hline Space group & Immm & Immm \\
\hline Crystal system & Orthorhombic & Orthorhombic \\
\hline$a / \AA$ & $14.6833(8)$ & $14.6181(7)$ \\
\hline$b / \AA$ & $17.0045(8)$ & $17.3106(15)$ \\
\hline$c / \AA$ & $17.9179(14)$ & $16.5365(8)$ \\
\hline$\alpha / \operatorname{deg}$ & 90 & 90 \\
\hline$\beta / \operatorname{deg}$ & 90 & 90 \\
\hline$\gamma / \operatorname{deg}$ & 90 & 90 \\
\hline$V / \AA^{3}$ & $4473.8(5)$ & $4184.5(5)$ \\
\hline$Z$ & 16 & 16 \\
\hline$D_{\mathrm{c}} / \mathrm{g} \mathrm{cm}^{-3}$ (solvent-free) & 0.576 & 0.616 \\
\hline$\mu / \mathrm{mm}^{-1}$ & 0.188 & 0.201 \\
\hline$F(000)$ & 808.0 & 808.0 \\
\hline$R 1[I \geq 2 \sigma(I)]$ & 0.0702 & 0.0903 \\
\hline$w R 2$ [all data] & 0.2307 & 0.2878 \\
\hline
\end{tabular}


Table S2. The experimental values for selected distances and angles of $\mathrm{C}-\mathrm{H}^{\delta+} \cdots \mathrm{H}^{\delta^{-}}-\mathrm{B}$ DHBs interactions of $1 \cdot 5 \mathrm{C}_{2} \mathrm{Cl}_{4} \cdot 4 \mathrm{CH}_{3} \mathrm{OH}$ at $123 \mathrm{~K}$.

\begin{tabular}{|c|c|c|c|c|}
\hline entry & $\mathrm{C}-\mathrm{H} \cdots \mathrm{H}-\mathrm{B}$ & $\mathrm{H} \cdots \mathrm{H}(\AA)$ & $\mathrm{C}-\mathrm{H} \cdots \mathrm{H}\left({ }^{\circ}\right)$ & $\mathrm{H}^{\cdots} \cdot \mathrm{H}-\mathrm{B}\left({ }^{\circ}\right)$ \\
\hline 1 & $\begin{array}{c}\mathrm{C} \# 1 \quad 10-\mathrm{H} \# 1 \quad 10 \cdots \mathrm{H} \# 1 \quad 1 \mathrm{C}-\mathrm{B} \# 1 \\
1\end{array}$ & 2.5811 & 122.228 & 98.788 \\
\hline 2 & $\begin{array}{c}\mathrm{C} \# 1 \quad \text { 10-H\#1 } \\
10 \cdots \mathrm{H} \# 1 \text { 1A-B\#1 } \\
1\end{array}$ & 2.4735 & 162.539 & 104.488 \\
\hline 3 & 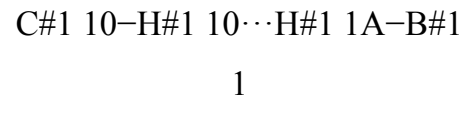 & 2.3100 & 140.151 & 137.956 \\
\hline 4 & $\mathrm{C \# 3} 9-\mathrm{H} \# 3 \quad 9 \cdots \mathrm{H} \# 1$ 1A-B\#1 1 & 2.4709 & 115.465 & 124.443 \\
\hline 5 & C\#4 10-H\#4 $10 \cdots \mathrm{H} \# 1$ 1B-B\#1 & 1.9847 & 145.951 & 139.962 \\
\hline 6 & C\#1 9-H\#1 $9 \cdots \mathrm{H} \# 2$ 1C-B\#2 1 & 2.2429 & 136.997 & 145.205 \\
\hline 7 & $\begin{array}{c}\mathrm{C} \# 3 \text { 10-H\#3 } 10 \cdots \mathrm{H} \# 2 \text { 1A-B\#2 } \\
1\end{array}$ & 2.0175 & 140.298 & 136.570 \\
\hline 8 & 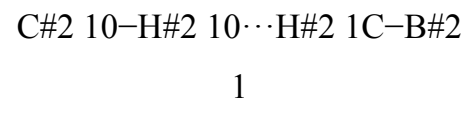 & 2.7332 & 120.949 & 91.263 \\
\hline 9 & $\begin{array}{c}\mathrm{C} \# 2 \quad 10-\mathrm{H} \# 2 \quad 10 \cdots \mathrm{H} \# 2 \text { 1B-B\#2 } \\
1\end{array}$ & 2.3329 & 163.572 & 112.646 \\
\hline 10 & 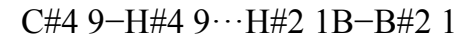 & 2.6078 & 112.220 & 115.204 \\
\hline
\end{tabular}

Table S3. Selected bond lengths and angles for $1 \cdot 5 \mathrm{C}_{2} \mathrm{Cl}_{4} \cdot 4 \mathrm{CH}_{3} \mathrm{OH}$ at $293 \mathrm{~K}$.

\begin{tabular}{ll}
\hline $\mathrm{Fe} 1-\mathrm{N} 1$ & $2.126(5)$ \\
$\mathrm{Fe} 1-\mathrm{N} 2$ & $2.215(3)$ \\
& \\
$\mathrm{N} 1-\mathrm{Fe} 1-\mathrm{N} 2$ & 90.0 \\
$\mathrm{~N} 1-\mathrm{Fe} 1-\mathrm{N} 1{ }^{\# 1}$ & 180.0 \\
$\mathrm{~N} 1-\mathrm{Fe} 1-\mathrm{N} 2{ }^{\# 1}$ & 90.0 \\
$\mathrm{~N} 1-\mathrm{Fe} 1-\mathrm{N} 2^{\# 2}$ & 90.0
\end{tabular}




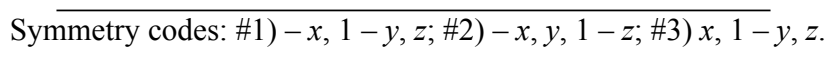

Table S4. Selected bond lengths and angles for $1 \cdot 5 \mathrm{C}_{2} \mathrm{Cl}_{4} \cdot 4 \mathrm{CH}_{3} \mathrm{OH}$ at $123 \mathrm{~K}$.

\begin{tabular}{ll}
\hline $\mathrm{Fe} 1-\mathrm{N} 1$ & $1.927(5)$ \\
$\mathrm{Fe} 1-\mathrm{N} 2$ & $1.998(3)$ \\
& \\
$\mathrm{N} 1-\mathrm{Fe} 1-\mathrm{N} 2$ & 90.000 \\
$\mathrm{~N} 1-\mathrm{Fe} 1-\mathrm{N} 1^{\# 1}$ & 180.0 \\
$\mathrm{~N} 1-\mathrm{Fe} 1-\mathrm{N} 2{ }^{\# 1}$ & 90.000 \\
$\mathrm{~N} 1-\mathrm{Fe} 1-\mathrm{N} 2^{\# 2}$ & 90.000 \\
$\mathrm{~N} 1-\mathrm{Fe} 1-\mathrm{N} 2^{\# 3}$ & 90.000 \\
\hline
\end{tabular}

Symmetry codes: \#1) $-x, 1-y, z$; \#2)-x,y,1-z;\#3) $x, 1-y, 1-z$.

\section{Additional Figures}

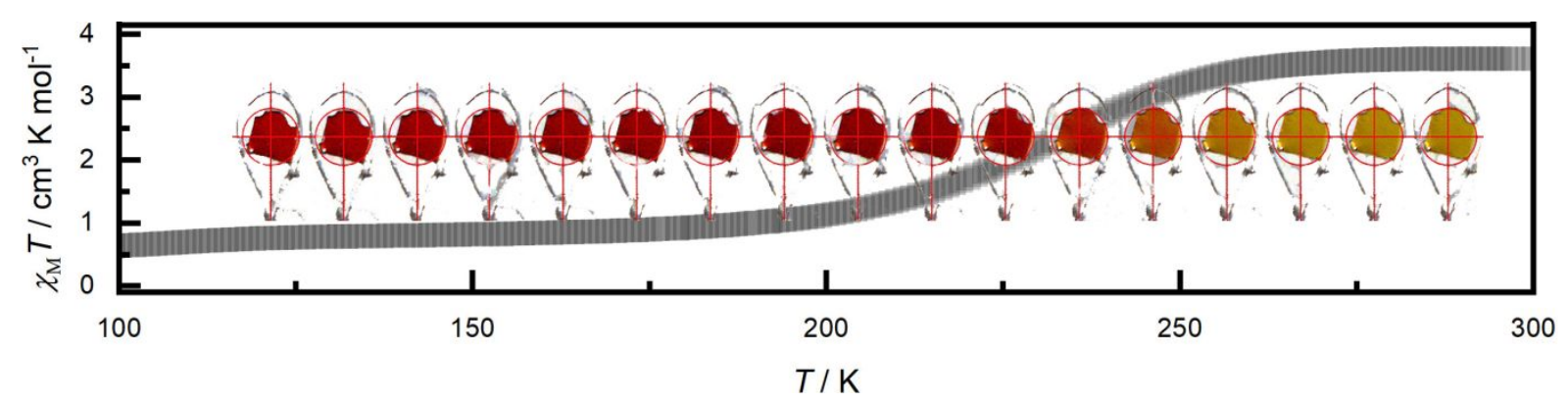

Figure S1. Temperature-dependent $\chi_{\mathbf{M}} \boldsymbol{T}$ values and variable-temperature crystal colours of $1 \cdot 5 \mathrm{C}_{2} \mathrm{Cl}_{4} \cdot 4 \mathrm{CH}_{3} \mathrm{OH}$. 


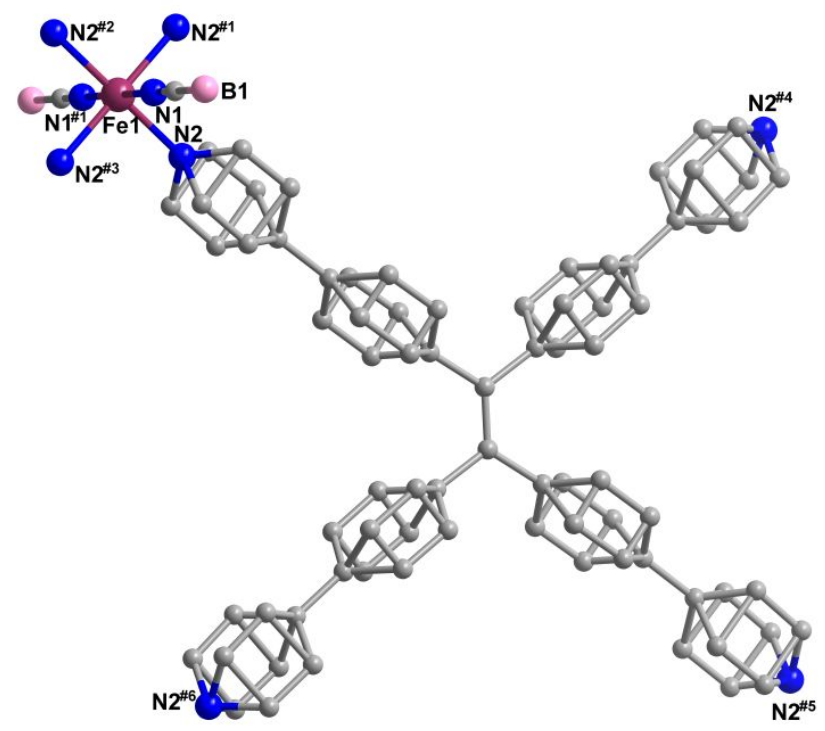

Figure S2. Coordination environment of the $\mathrm{Fe}^{\mathrm{II}}$ atom in $\mathbf{1} \cdot 5 \mathrm{C}_{2} \mathrm{Cl}_{4} \cdot 4 \mathrm{CH}_{3} \mathrm{OH}$ at $298 \mathrm{~K}$ and $123 \mathrm{~K}$ (Table S3, S4).

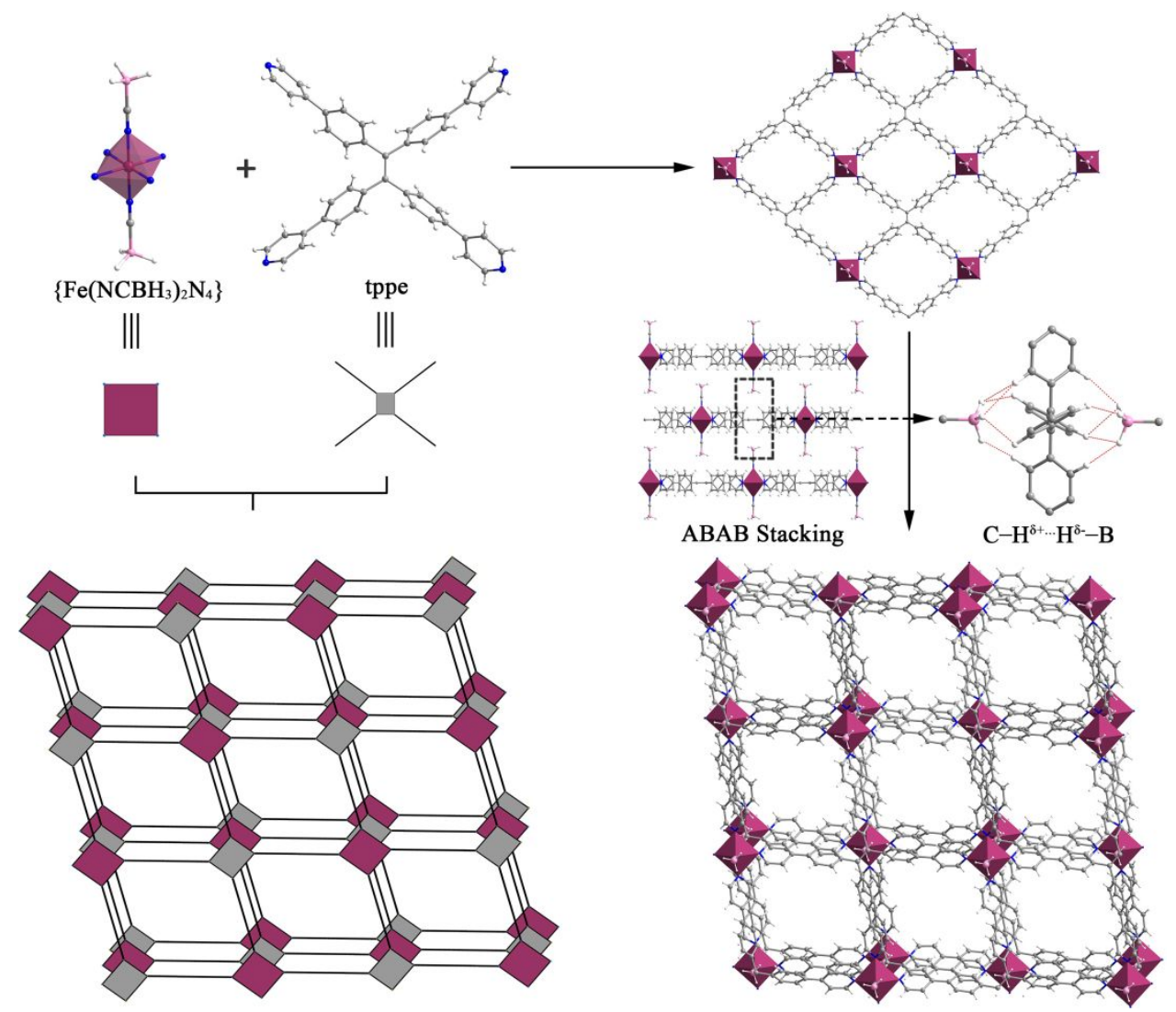

Figure S3. The supramolecular structure of $1 \cdot 5 \mathrm{C}_{2} \mathrm{Cl}_{4} \cdot 4 \mathrm{CH}_{3} \mathrm{OH}$. 


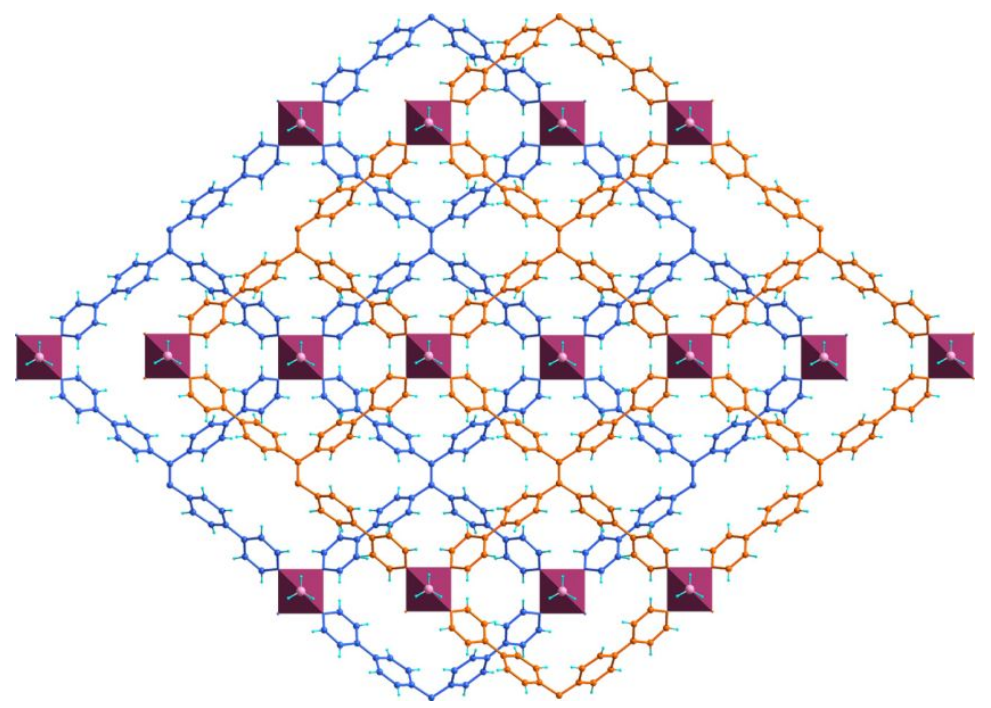

Figure S4. Another imaginary ABAB-stacked structure, in which the $\mathbf{N C B H}_{\mathbf{3}}^{-}$groups point to the windows of adjacent layers.

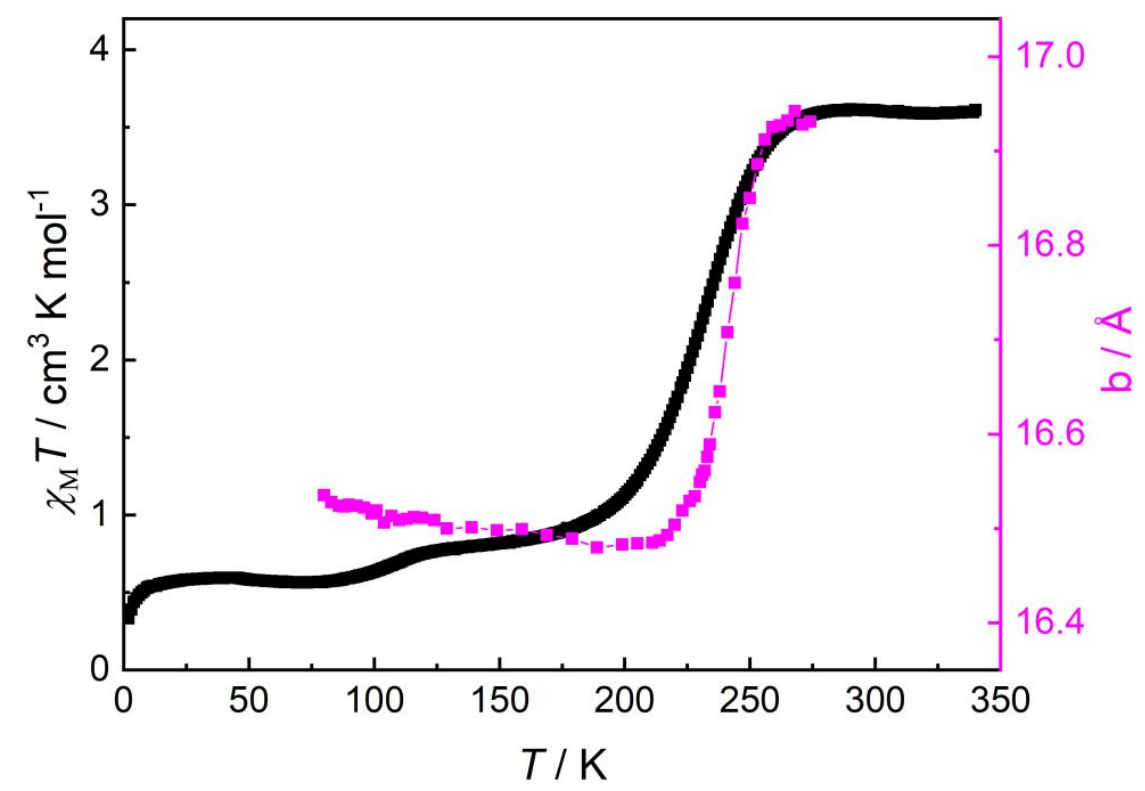

Figure S5. Temperature-dependent $\chi_{\mathbf{M}} \boldsymbol{T}$ values and the variable-temperature $b$-axis values of $\mathbf{1} \cdot 5 \mathrm{C}_{2} \mathrm{Cl}_{4} \cdot 4 \mathrm{CH}_{3} \mathrm{OH}$. 


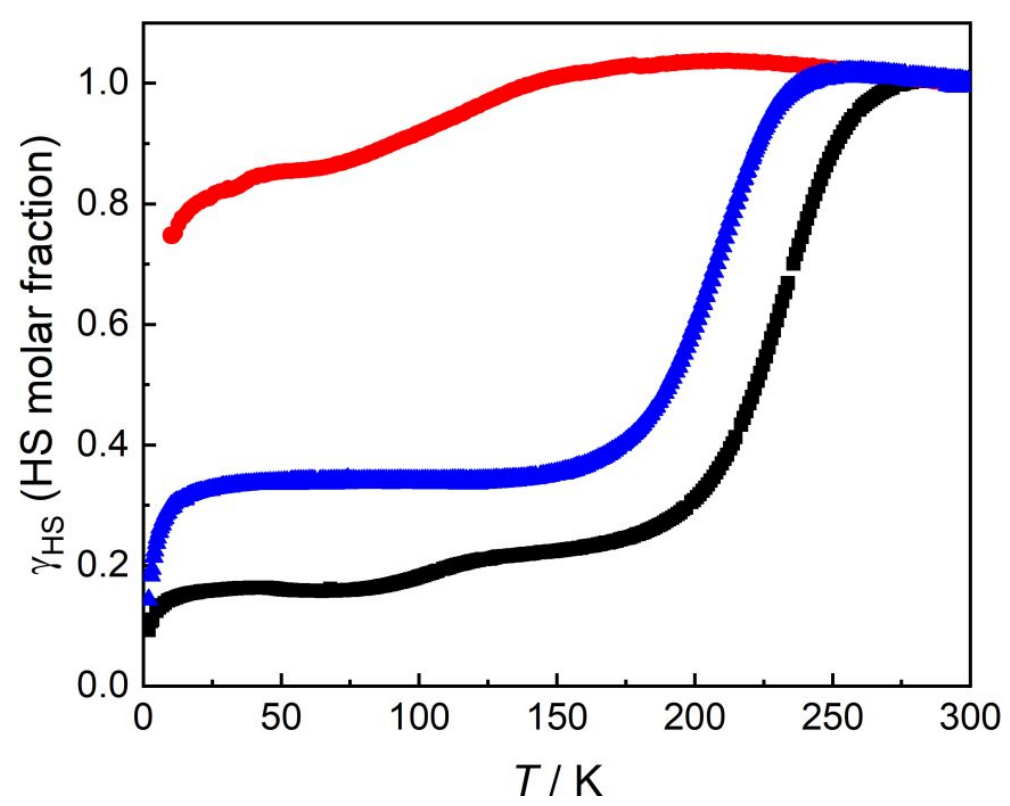

Figure S6. Temperature-dependent $\chi_{\mathbf{M}} \boldsymbol{T}$ values of $\mathbf{1} \cdot 5 \mathrm{C}_{2} \mathrm{Cl}_{4} \cdot 4 \mathrm{CH}_{3} \mathrm{OH}$ (black), $\mathbf{1} \cdot 3 \mathrm{CHCl}_{3} \cdot 4 \mathrm{CH}_{3} \mathrm{OH}$ (blue), and $\mathbf{1} \cdot 2 \mathrm{C}_{6} \mathrm{H}_{6} \cdot 4 \mathrm{CH}_{3} \mathrm{OH}$ (red).

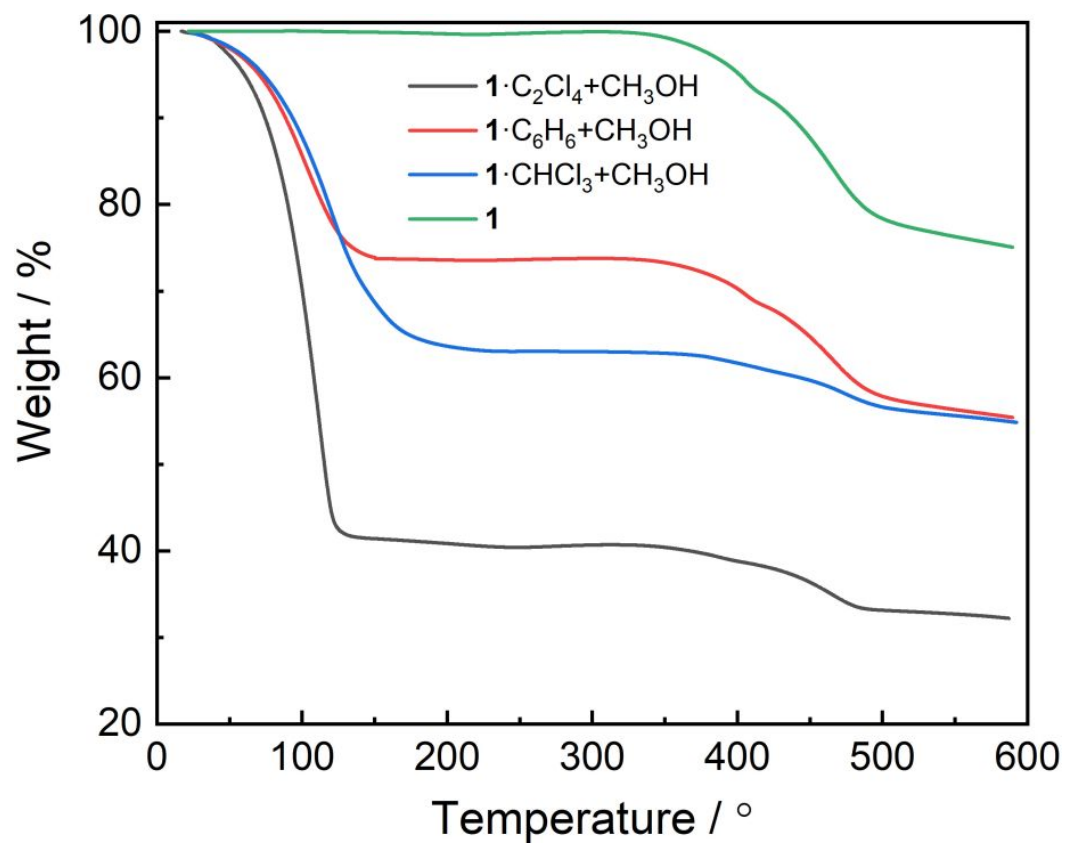

Figure S7. Thermogravimetric analysis of $1 \cdot 5 \mathrm{C}_{2} \mathrm{Cl}_{4} \cdot 4 \mathrm{CH}_{3} \mathrm{OH}, \mathbf{1} \cdot 3 \mathrm{CHCl}_{3} \cdot 4 \mathrm{CH}_{3} \mathrm{OH}, \mathbf{1} \cdot 2 \mathrm{C}_{6} \mathrm{H}_{6} \cdot 4 \mathrm{CH}_{3} \mathrm{OH}$, and 1 . 


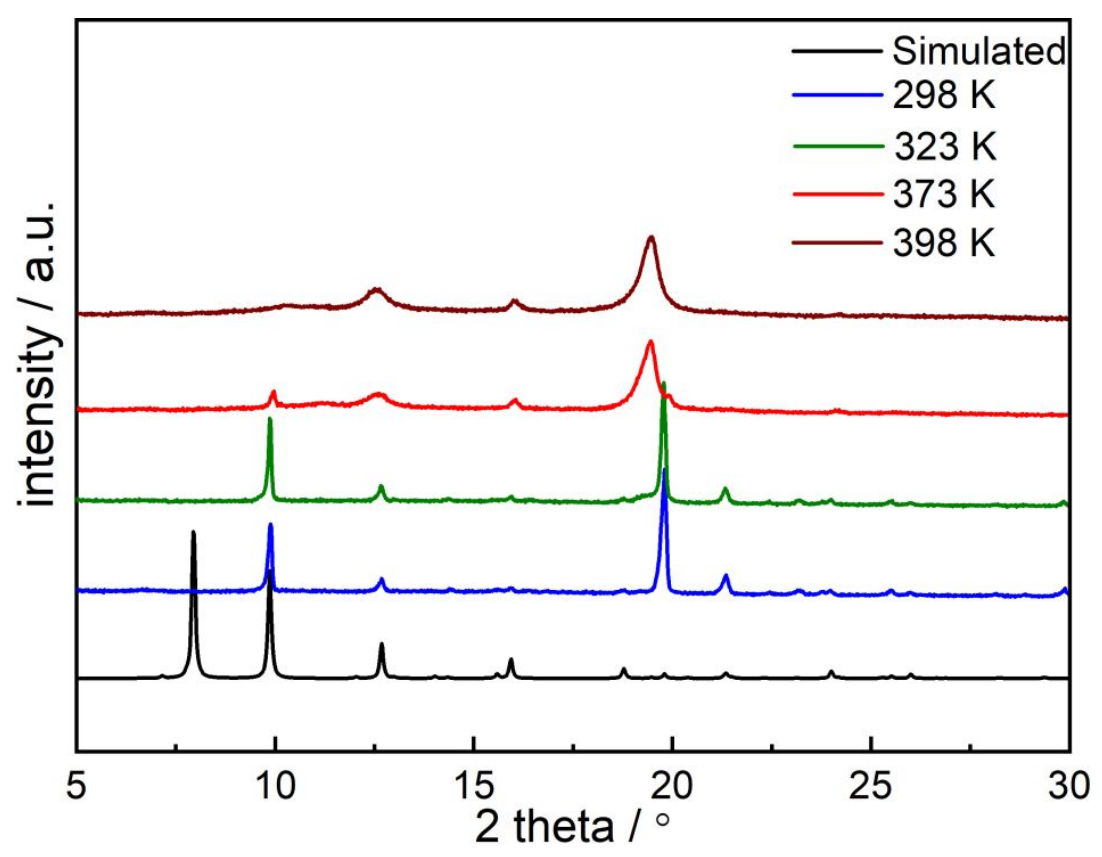

(a)

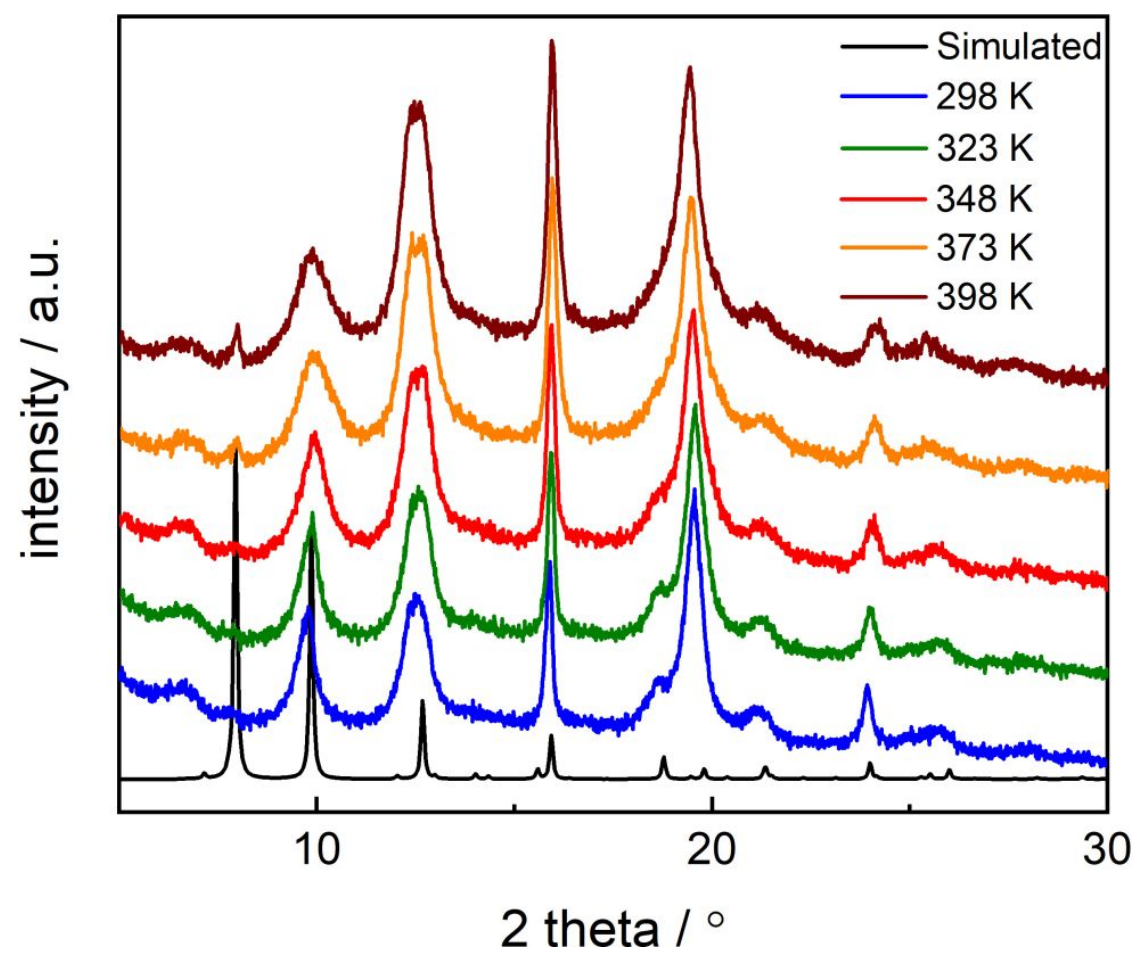

(b)

Figure S8. Variable-temperature powder X-ray diffraction pattern of compound $1 \cdot 5 \mathrm{C}_{2} \mathrm{Cl}_{4} \cdot 4 \mathrm{CH}_{3} \mathrm{OH}$ in freshly prepared state (a) and stored for 6 months (b). 


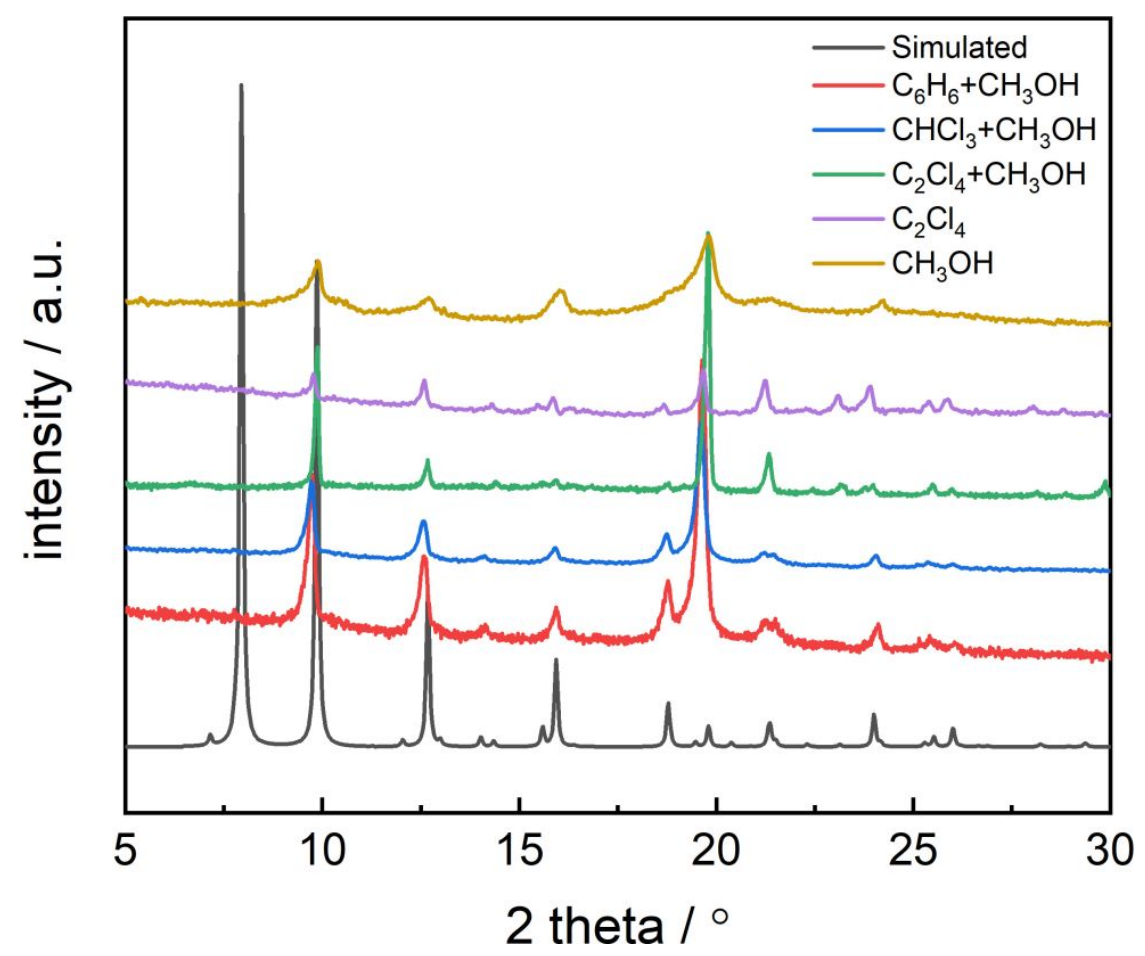

Figure S9. Powder X-ray diffraction pattern of compounds of $1 \cdot 5 \mathrm{C}_{2} \mathrm{Cl}_{4} \cdot 4 \mathrm{CH}_{3} \mathrm{OH}, \mathbf{1} \cdot 3 \mathrm{CHCl}_{3} \cdot 4 \mathrm{CH}_{3} \mathrm{OH}$, $\mathbf{1} \cdot 2 \mathrm{C}_{6} \mathrm{H}_{6} \cdot 4 \mathrm{CH}_{3} \mathrm{OH}$ and 1 encapsulating $\mathrm{CH}_{3} \mathrm{OH}$ and $\mathrm{C}_{2} \mathrm{Cl}_{4}$ at $298 \mathrm{~K}$.
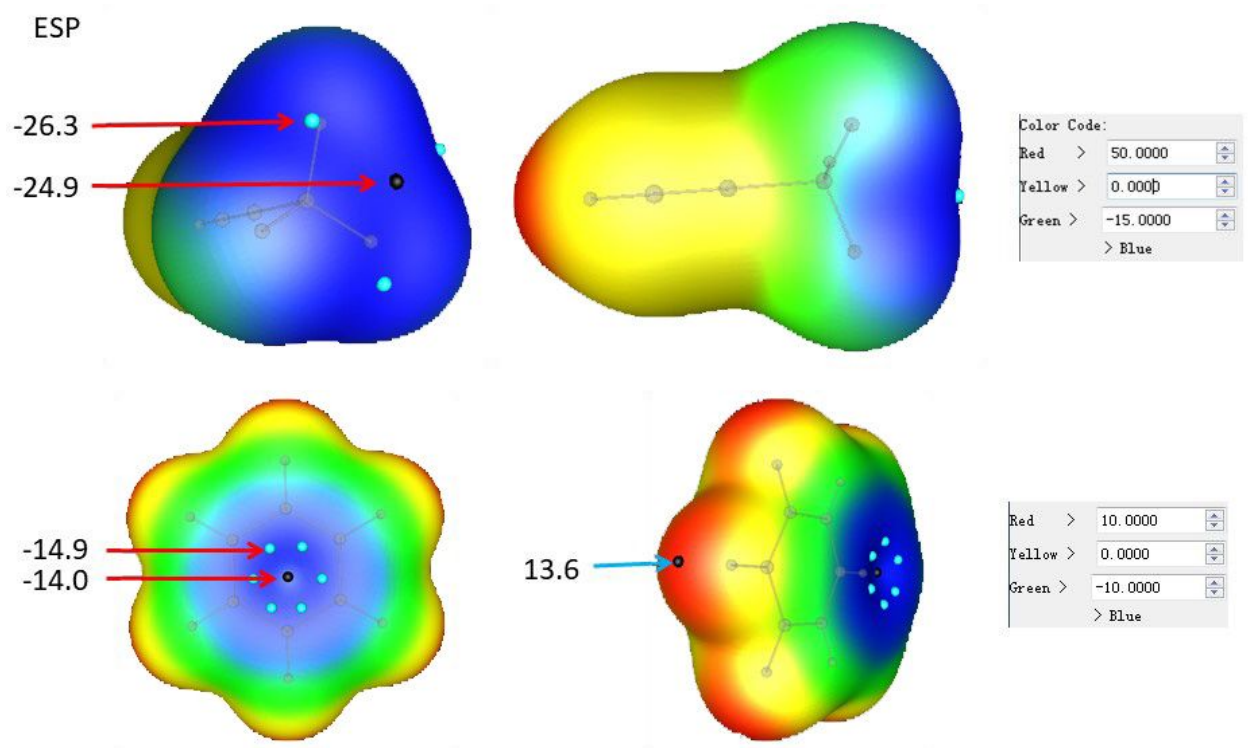

Figure S10. Electrostatic potential diagram and extreme value of $\mathrm{C}_{6} \mathrm{H}_{6} \cdots\left[\mathrm{NCBH}_{3}^{-}\right]$complex. 


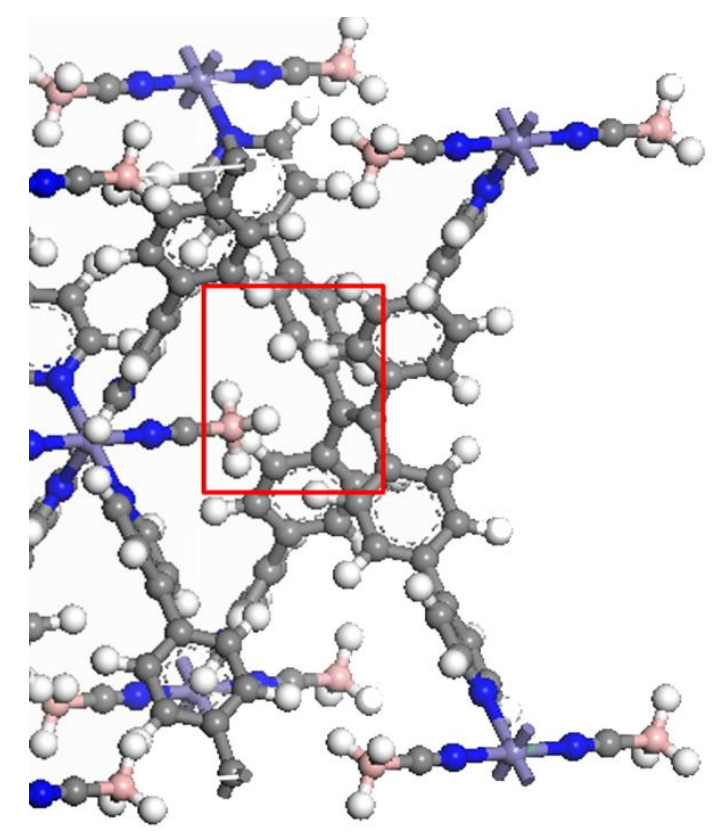

(1)

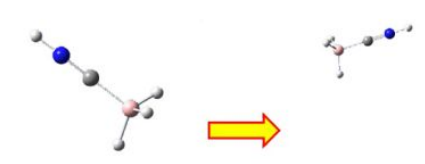

(2)
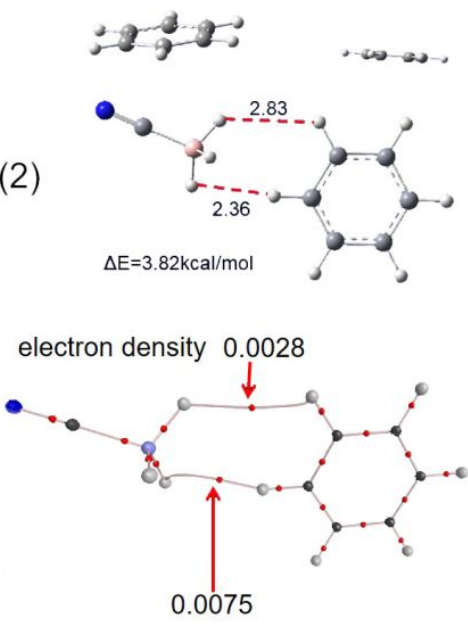

Figure S11. The dihydrogen bonds portion in the structure and electron density and molecular configuration of $\mathrm{C}_{6} \mathrm{H}_{6} \cdots\left[\mathbf{N C B H}_{3}^{-}\right]$complex.

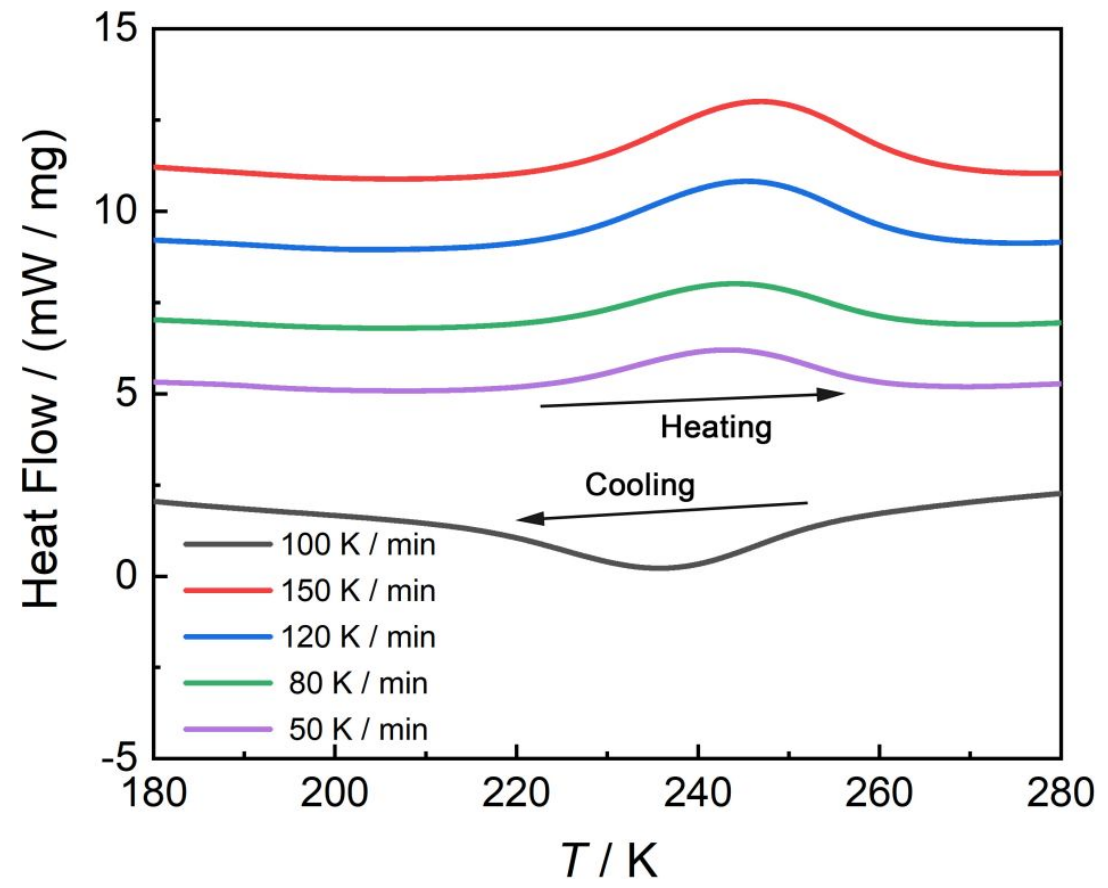

Figure S12. DSC data of compound $1 \cdot 5 \mathrm{C}_{2} \mathrm{Cl}_{4} \cdot 4 \mathrm{CH}_{3} \mathrm{OH}$. 


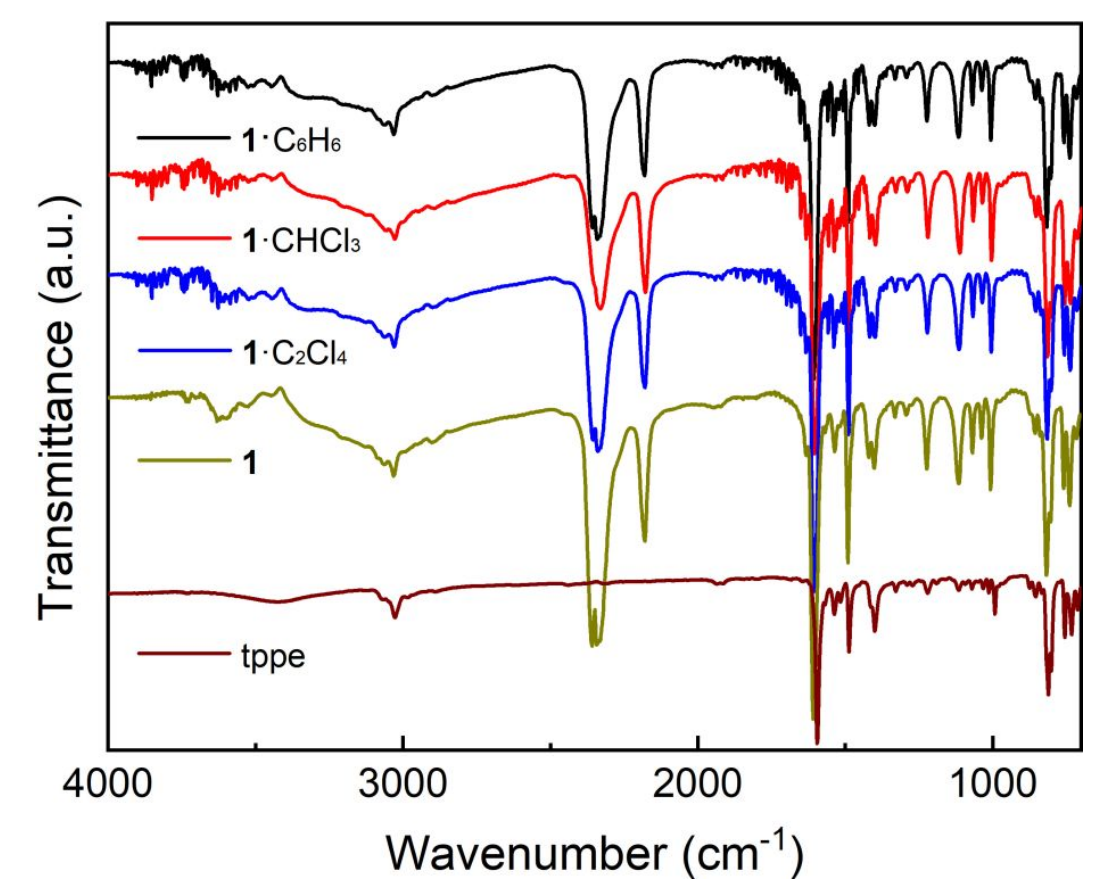

Figure S13. IR spectra of compounds $\mathbf{1} \cdot 5 \mathrm{C}_{2} \mathrm{Cl}_{4} \cdot 4 \mathrm{CH}_{3} \mathrm{OH}, \mathbf{1} \cdot 3 \mathrm{CHCl}_{3} \cdot 4 \mathrm{CH}_{3} \mathrm{OH}, \mathbf{1} \cdot 2 \mathrm{C}_{6} \mathrm{H}_{6} \cdot 4 \mathrm{CH}_{3} \mathrm{OH}, \mathbf{1}$ and tppe.

\section{References}

(1) (a) Altomare, A.; Burla, M. C.; Camalli, M.; Cascarano, G. L.; Giacovazzo, C.; Guagliardi, A.; Moliterni, A. G. G.; Polidori, G.; Spagna, R. J. Appl. Crystallogr. 1999, 32, b115; (b) Sheldrick, G. M.; SHELXL-97; Program for refinement of crystal structures. University of Göttingen, Göttingen, Germany, 1997.

(2) (a) Spek, A. L. Utrecht University: Utrecht, The Netherlands, 1998; (b) Spek, A. L. Acta Cryst. 2009, D65, 148.

(3) (a) Taylor, R.; Macrae, C. F.; Acta Cryst. 2001, B57, 815. (b) Bruno, I. J.; Cole, J. C.; Edgington, P. R.; Kessler, M. K.; Macrae, C. F.; McCabe, P.; Pearson J.; Taylor R. Acta Cryst. 2002, B58, 389; (c) Macrae, C. F.; Edgington, P. R.; McCabe, P.; Pidcock, E.; Shields, G. P.; Taylor, R.; Towler, M.; van de Streek, J. J. Appl. Cryst. 2006, 39, 453; (d) Macrae, C. F.; Bruno, I. J.; Chisholm, J. A.; Edgington, P. R.; McCabe, P.; Pidcock, E.; Rodriguez-Monge, L.; Taylor, R.; van de Streek, J.; Wood, P. A. J. Appl. Cryst. 2008, 41,466 .

(4) (a) Stratmann, R. E.; Scuseria, G. E.; Frisch, M. J. J. Chem. Phys. 1998, 109, 8218; (b) Bauernschmitt, R.; Ahlrichs, R. Chem. Phys. Lett. 1996, 256, 454; (c) Casida, M. E.; Jamorski, C.; Casida, K. C.; Salahub, D. R. J. Chem. Phys. 1998, 108, 4439.

(5) Bernardi, F.; Boys, S. F. Mol. Phys. 1970, 19, 553.

(6) Frisch, M. J.; Trucks, G. W.; Schlegel, H. B.; Scuseria, G. E.; Robb, M. A.; Cheeseman, J. R.; Scalmani, G.; Barone, V.; Mennucci, B.; Petersson, G. A.; Nakatsuji, H.; Caricato, M.; Li, X.; Hratchian, H. P.; Izmaylov, A. F.; Bloino, J.; Zheng, G.; Sonnenberg, J. L.; Hada, M.; Ehara, M.; Toyota, K.; Fukuda, R.; Hasegawa, J.; Ishida, M.; Nakajima, T.; Honda, Y.; Kitao, O.; Nakai, H.; Vreven, T.; Montgomery, J. A.; Jr.; Peralta, J. E.; Ogliaro, F.; Bearpark, M.; Heyd, J. J.; Brothers, E.; Kudin, K. N.; Staroverov, V. N.; Keith, T.; Kobayashi, R.; Normand, J.; Raghavachari, K.; Rendell, A.; Burant, J. C.; Iyengar, S. S.; Tomasi, J.; Cossi, M.; Rega, N.; Millam, J. M.; Klene, M.; Knox, J. E.; Cross, J. B.; Bakken, V.; Adamo, C.; Jaramillo, J.; Gomperts, R.; Stratmann, R. E.; Yazyev, O.; Austin, A. J.; Cammi, R.; Pomelli, C.; Ochterski, J. W.; Martin, R. L.; Morokuma, K.; Zakrzewski, V. G.; Voth, G. A.; Salvador, P.; Dannenberg, J. J.; Dapprich, S.; Daniels, A. D.; Farkas, O.; Foresman, J. B.; Ortiz, J. V.; Cioslowski, J.; Fox, D. J. Gaussian 09 D.01. Gaussian, Inc.: Wallingford CT, 2013. 